\title{
Assessing Nutrient Elements as Indicators for Soil Active Organic Carbon in Topsoil of Karst Areas
}

\author{
Husen Qiu' ${ }^{1-3}$, Jieyun Liu', Lei Li ${ }^{1}$, Kunping Liu ${ }^{1,2}$, \\ Xunyang $\mathrm{He}^{1,2}$, Yirong $\mathrm{Su}^{1,2 *}$ \\ ${ }^{1}$ Key Laboratory of Agro-ecological Processes in Subtropical Region, Institute of Subtropical Agriculture, \\ Chinese Academy of Sciences, Changsha, China \\ ${ }^{2}$ Huanjiang Observation and Research Station for Karst Eco-Systems, Chinese Academy of Sciences, \\ Huanjiang, China \\ ${ }^{3}$ University of Chinese Academy of Sciences, Beijing, China
}

Received: 11 December 2017

Accepted: 28 February 2018

\begin{abstract}
In karst areas, in order to ascertain the relationship between soil active organic carbon fractions and soil nutrient elements, topsoil samples (the sampling points were set at $80-\mathrm{m}$ intervals) were collected for the analysis of soil physicochemical properties. In the sampling area, land use was divided into upland, paddy, and shrub land. The results showed that dissolved organic $\mathrm{C}$ (DOC) and microbial biomass $\mathrm{C}(\mathrm{MBC})$ contents in shrub land soil were higher than those values in upland and paddy soils $(p<0.05)$. The total nitrogen (TN) content in paddy was lower than in upland and shrub land $(p<0.05)$. The mean value of total phosphorus (TP) in upland and shrub land was approximately 1.5 times higher than that in paddy. Available nitrogen (AN) in shrub land soil was higher than in upland, whereas Olsen-P was lowest in shrub land in all soils $(p<0.05)$. The C:P and N:P ratios in upland and paddy were lower than in shrub land $(p<0.05)$. At plot scale, random forest analysis revealed that $\mathrm{pH}$ and soil organic carbon (SOC) were the most important variables determining DOC content in croplands (upland and paddy) and shrub land, respectively. The accumulation of SOC accelerates the growth of microbial biomass in upland. In shrub land, increases in SOC and total nitrogen were in favor of microbial growth. At the small-watershed scale, C:P and N:P ratios had a significant and positive effect on the content of DOC and $\mathrm{MBC}$, respectively. The results implied that high $\mathrm{C}$ and $\mathrm{N}$ availability, especially in combination with low $\mathrm{P}$ availability, is helpful for increasing soil microbial biomass.
\end{abstract}

Keywords: ecological stoichiometry, soil nutrient, active organic carbon fractions, land use, karst area

*e-mail: yrsu@isa.ac.cn 


\section{Introduction}

Soil nitrogen $(\mathrm{N})$ and phosphorus $(\mathrm{P})$ cycling are tightly coupled to carbon (C) cycling in a terrestrial ecosystem [1]. Dissolved organic carbon (DOC) and soil microbial biomass carbon $(\mathrm{MBC})$ are the small part of the soil organic carbon (SOC) pool, whereas they play an important role in the soil carbon biogeochemical cycle [2]. Previous studies have suggested that the amount of soil active organic carbon depends on the relative ratio of C:N:P [3-4]. Nosrati et al. [5] found that the amount of DOC increased with increasing soil organic carbon content in a semi-arid drainage basin. At high $\mathrm{C}: \mathrm{N}$ ratios, mineralization rate of the available DOC is limited and the DOC concentration increases [6]. In short, $\mathrm{C}: \mathrm{N}$ ratio was a useful indicator of the content of DOC. MBC respond rapidly to land management practices and can be used as a sensitive indicator of changes in soil organic matter [7]. The soil microbial biomass acts as both sink and source of nutrients. The availability and limitation of essential nutrients can thus provide feedback on microbial biomass and SOC dynamics. On a global scale, soil microbial carbon pools were somewhat correlated with soil C:P and N:P ratios, although a weak general relationship between soil $\mathrm{P}$ and MBC could be described for pastures and forest soils [8]. Schimel and Weintraub [9] consider that $\mathrm{N}$ availability directly constrains the size of microbial $\mathrm{C}$ pools across global soils. Sinsabaugh et al. [10] deem that microbial allocation to $\mathrm{P}$ uptake is considerably greater than that of $\mathrm{C}$ and $\mathrm{N}$ when compared to requirements for the growth of biomass. In general, the effects of availability of nutrients on biomass growth were quite different.

Land use types affect the amount of soil nutrients and SOC sequestration [11-12]. In karst areas, numerous studies were mainly focused on ecological restoration to improve fragile ecosystems, soil fertility, and SOC sequestration. Previous studies have indicated that soil physicochemical properties have been improved after restoration [13]. However, the relative dynamics and dependencies among $\mathrm{C}, \mathrm{N}$, and $\mathrm{P}$ in karst areas have not been well investigated. Notably, studies on the relationships between soil active organic carbon fractions and soil nutrients at different scales are lacking (such as plot scale and the watershed scale) [14-15]. Better knowledge on the contribution of soil C, $\mathrm{N}$, and $\mathrm{P}$ ecological stoichiometries on soil active organic carbon fractions can provide the necessary information to develop effective measures for the rational utilization and management of land so as to enhance the potential capacity of SOC [16]. We proposed that the contribution of nutrient elements on active organic carbon fractions were discrepant with different land management, human disturbance, and scales. Thus, in this study,

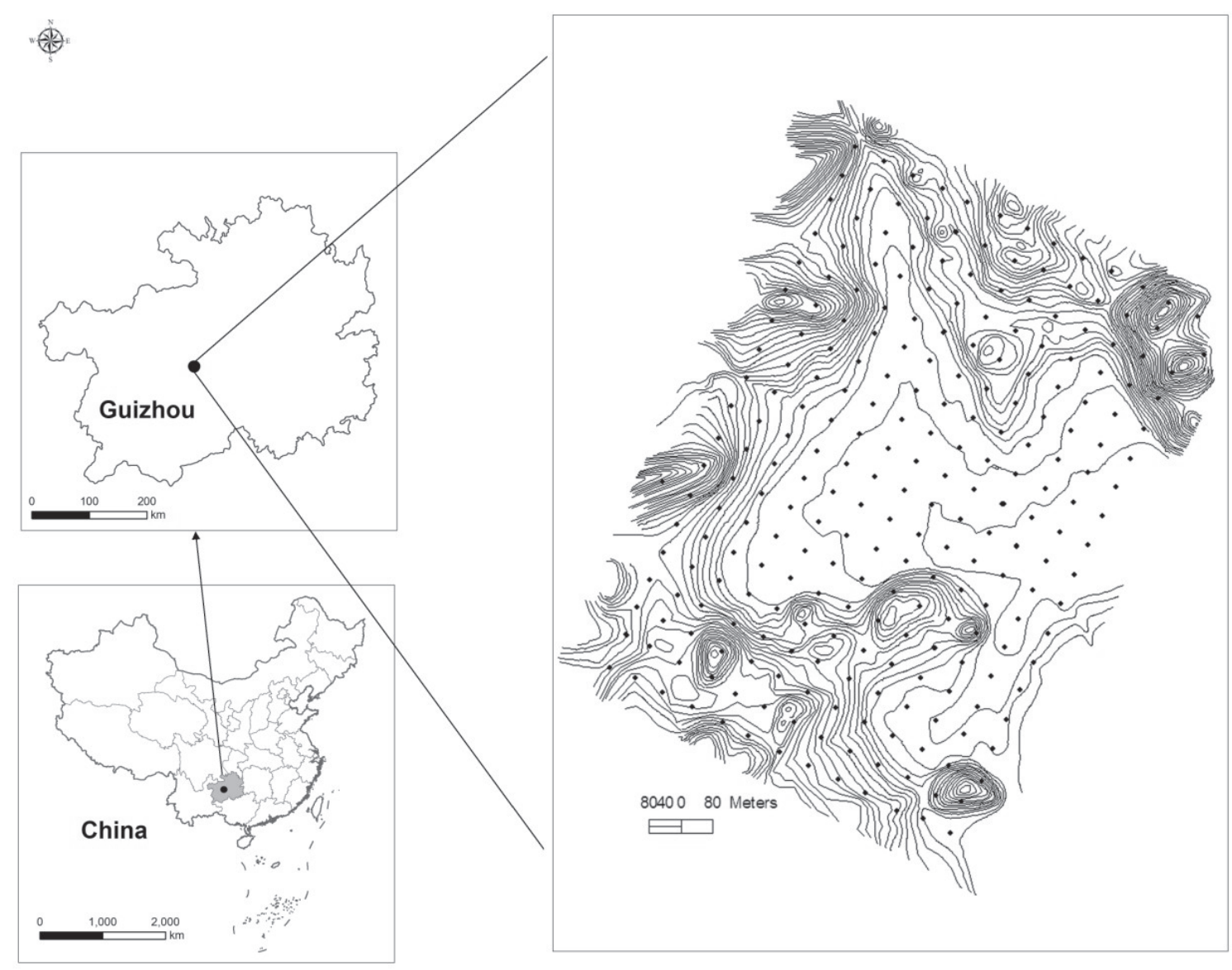

Fig. 1. Basic features of the sample plots. 

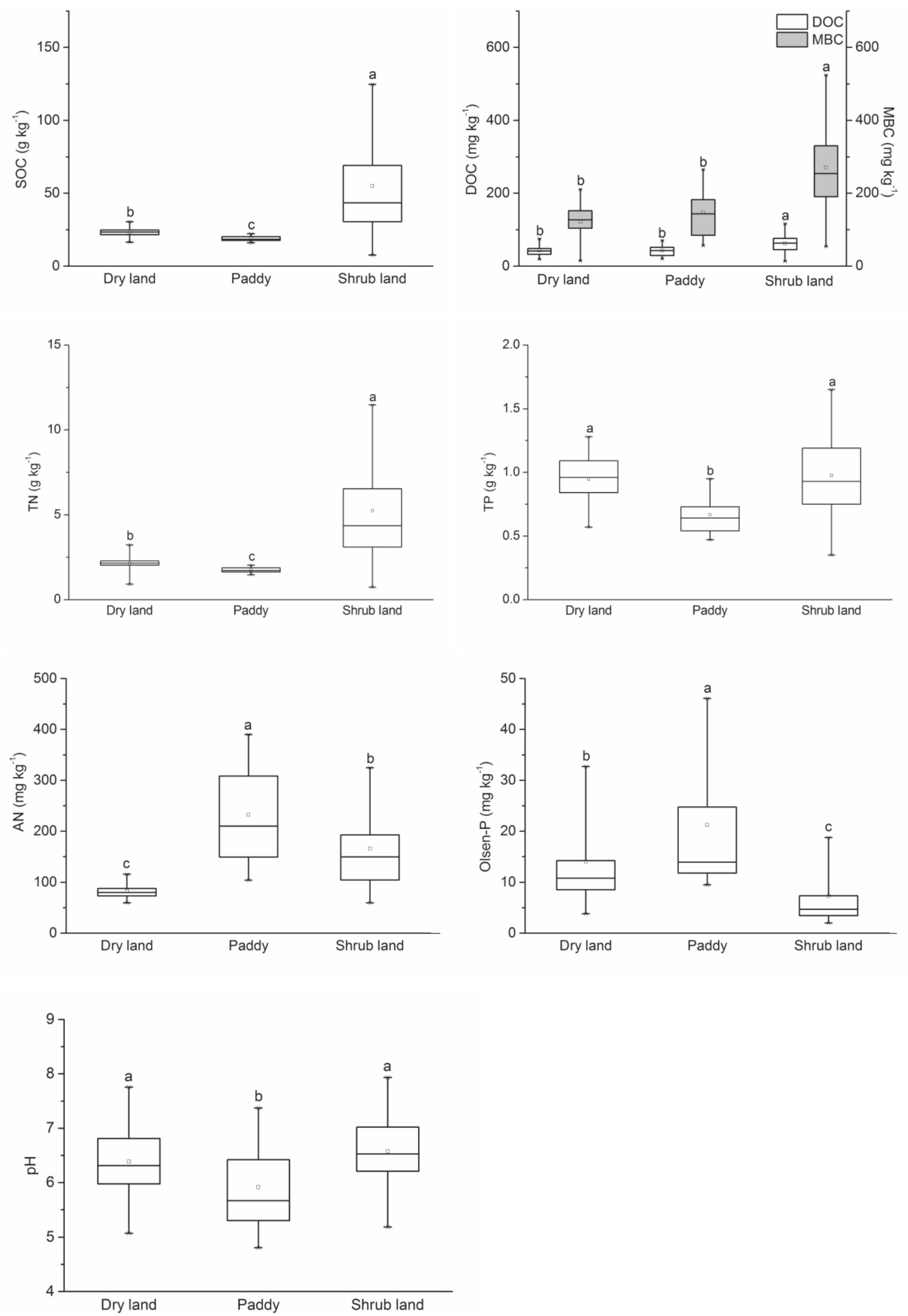

Fig. 2. Change of SOC $\left(\mathrm{g} \mathrm{kg}^{-1}\right)$, DOC $\left(\mathrm{mg} \mathrm{kg}^{-1}\right), \mathrm{MBC}\left(\mathrm{mg} \mathrm{kg}^{-1}\right), \mathrm{TN}\left(\mathrm{g} \mathrm{kg}^{-1}\right)$, TP $\left(\mathrm{g} \mathrm{kg}^{-1}\right), \mathrm{AN}\left(\mathrm{mg} \mathrm{kg}^{-1}\right)$, Olsen-P $\left(\mathrm{mg} \mathrm{kg}^{-1}\right)$, and $\mathrm{pH}$ in topsoil under different land use types $(p<0.05$; in dry land $\mathrm{n}=97$; in paddy $\mathrm{n}=19$; in shrub land $\mathrm{n}=132$ ). 
we aimed to: 1) assess the changes of active organic carbon fractions and nutrient elements, 2) distinguish the effects of nutrient elements on active organic carbon fractions under different land uses, and 3) evaluate the relationships between soil $\mathrm{C}: \mathrm{N}: \mathrm{P}$ stoichiometry and active organic carbon fractions at watershed scale.

\section{Material and Methods}

\section{Study Site}

The experimental site is located in the small watershed of Wang $\left(106^{\circ} 20^{\prime} 5^{\prime \prime}-106^{\circ} 21^{\prime} 8^{\prime \prime} \mathrm{E}, 26^{\circ} 31^{\prime} 45^{\prime \prime}\right.$ $\left.26^{\circ} 30^{\prime} 27^{\prime \prime} \mathrm{N}\right)$ situated in Boluo village, Qingzhen City, Guizhou Province, China. The area is a typical karst plateau with a peak cluster-depression ratio of approximately $1.65: 1$. The study region is characterized by a subtropical humid monsoon climate with an average annual precipitation of $1200 \mathrm{~mm}$, mainly concentrated in 5-9 months. The altitude is $1271-1451 \mathrm{~m}$, and the slope gradient ranges from $20^{\circ}$ to $60^{\circ}$. In the depression, land is mainly used as agricultural land, whereas the slopes are covered with grass and shrub. The main species include Zanthoxylum esquirolii, Rosa cymosa, Pyracantha fortuneana, and Broussonetia papyrifera; Rosa cymosa, Pyracantha fortuneana, Zanthoxylum armatum, and Sinopteris grevilleoides; and Themeda japonica, Carex lanceolata, Campylotrops macrocarpa, and Pyracantha fortuneana.

\section{Field Investigation, Soil Sampling, and Laboratory Analysis}

As shown in Fig. 1, the sampling points were set at $80-\mathrm{m}$ intervals and located by GPS (Trimble GeoXT3000). Environmental factors of every sampling point, including parent material, vegetation types and coverage, altitude, slope position, slope steepness and aspect, soil depth, and bare-rock ratio, were recorded. The bare-rock ratio was estimated by using frames $(1 \times 1 \mathrm{~m})$ containing grids $(10 \times 10 \mathrm{~cm})$. Ten measurements of soil depth around the sampling point were taken by pressing an iron stick marked at $10 \mathrm{~cm}$ intervals. At each sampling site, 5-8 soil cores from the surface soil $(0-15 \mathrm{~cm})$ were collected and bulked. A total of 248 representative soil samples were collected (with 97 samples in upland, 19 samples in paddy, and 132 samples in shrub land).

All the soil samples were sieved through a $2-\mathrm{mm}$ mesh and divided into two parts. One part was air-dried for analysis of physicochemical properties. The other part was immediately stored at $4^{\circ} \mathrm{C}$ and subsequently incubated at $25^{\circ} \mathrm{C}$ for 2 weeks at $45 \%$ water-holding capacity before measuring the MBC. The SOC was assayed according to the Walkley-Black dichromate oxidation procedure [17]. Total nitrogen (TN) was determined according to the Kjeldahl method using a

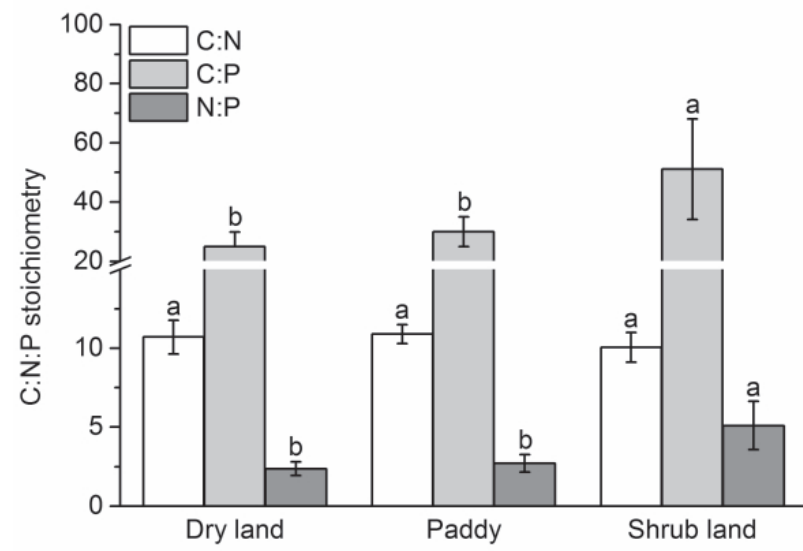

Fig. 3. Change of C:N, C:P, and N:P ratios under different land use types; values are means \pm standard deviations, $p<0.05$ (in dry land $\mathrm{n}=97$, in paddy $\mathrm{n}=19$, in shrub land $\mathrm{n}=132$ ).

flow-injection auto-analyzer (FIA Star 5000 Analyzer; Foss Tecator, Höganäs, Sweden) [18]. Total phosphorus (TP) was measured using $\mathrm{NaOH}$ digestion and the molybdenum blue colorimetric method [19]. Available nitrogen (AN) was determined using the micro-Kjeldahl method [20]. Available phosphorus (Olsen-P) was extracted using the sodium bicarbonate Olsen method [21]. DOC in the soil was extracted in duplicate with $0.5 \mathrm{M} \mathrm{K}_{2} \mathrm{SO}_{4}$, and the filtrate was analyzed using a TOC analyzer (TOC-VWP; Shimadzu Corp., Tokyo, Japan) for DOC. MBC of the soil was determined according to the fumigation-extraction method [22] using a TOC analyzer (TOC-VWP, Shimadzu Corporation, Japan).

\section{Statistical Analysis}

The means and standard errors of the data were calculated in Excel 2010 (Microsoft Corp., Redmond, WA, USA). Statistical analyses were performed using SPSS 11.5 (IBM, Chicago, IL, USA). Differences between $C: N, C: P$, and $N: P$ ratios were evaluated using one-way analysis of variance (ANOVA), followed by the Bonferroni test. Pearson correlation coefficients were calculated to quantify the correlation between soil active organic carbon fractions and nutrients The classification of random forests analysis was conducted to assess the most important drivers of nutrient elements and $\mathrm{pH}$ on the content of soil active organic carbon fractionS. These analyses were conducted using the RANDOMFOREST package [23] for the R statistical software, version 3.4.1.

\section{Results}

\section{Changes in $\mathrm{C}, \mathrm{N}$, and $\mathrm{P}$}

The mean SOC content in shrub land was 2-3 times higher than that in upland and paddy soils $(p<0.05)$. 
Similarly, the DOC and MBC in shrub land were higher than in the other two land use types ( $p<0.05$; Fig. 2). The TN content in paddy was lower than in upland and shrub land $(p<0.05)$. The mean value of TP in upland and shrub land was approximately 1.5 times higher than that in paddy. AN and Olsen-P in paddy were higher than in upland and shrub land. AN in shrub land was higher than in upland, whereas Olsen-P was lower in shrub land than in upland and paddy.

\section{$\mathrm{C}, \mathrm{N}$, and P Stoichiometry}

As shown in Fig. 3, the C:N ratio of soil was similar under all land use types (from 10 to 11), and all C:P ratios were below 55. The $\mathrm{C}: \mathrm{P}$ ratio in shrub land soil was approximately 1.5-2 times higher than that in upland and paddy $(p<0.05)$, but no difference was observed between upland and paddy. The N:P ratio was lower in the upland and paddy sites than in the shrub-land site, with mean values of 2.4, 2.7, and 5.1, respectively.
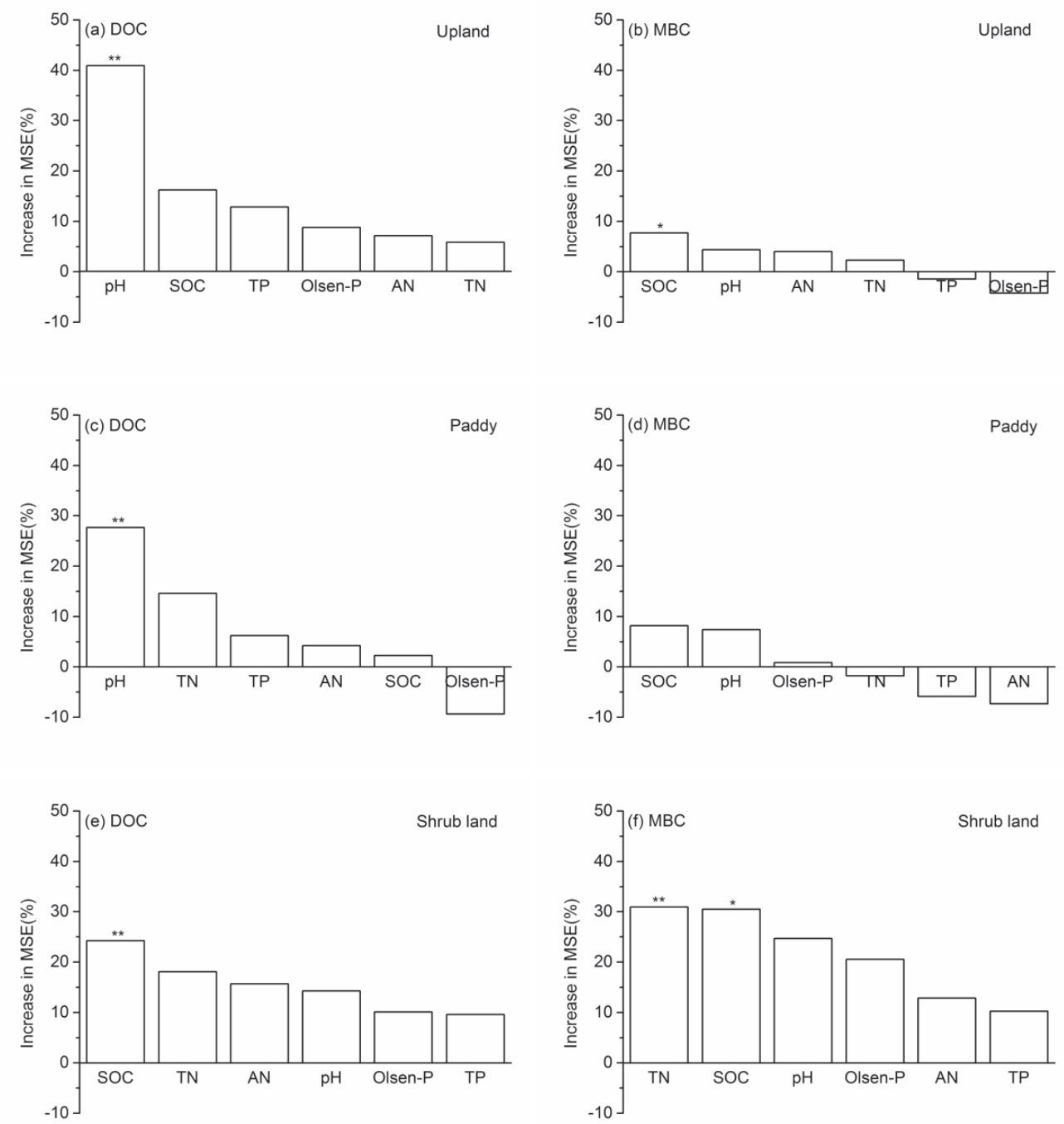

Contribution of Soil Nutrients and $\mathrm{pH}$ on Soil Active Organic Carbon Fractions

As shown in Fig. 4, random forest analysis revealed that $\mathrm{pH}$ was the most important variable affecting the amount of DOC in upland and paddy soils. In shrub land, SOC was the important factor determining the content of DOC, whereas SOC and TN affected the content of $\mathrm{MBC}$. In the sample area, the $\mathrm{C}: \mathrm{P}$ ratio affected the content of DOC, and $\mathrm{N}: \mathrm{P}$ ratio affected the content of MBC (Fig. 5, p<0.05).

\section{Discussion}

\section{Change in Soil C, N, and P under Different Land Uses}

Land use has been shown to have significant impacts on the cycling of soil $\mathrm{C}, \mathrm{N}$, and $\mathrm{P}$, and on their 

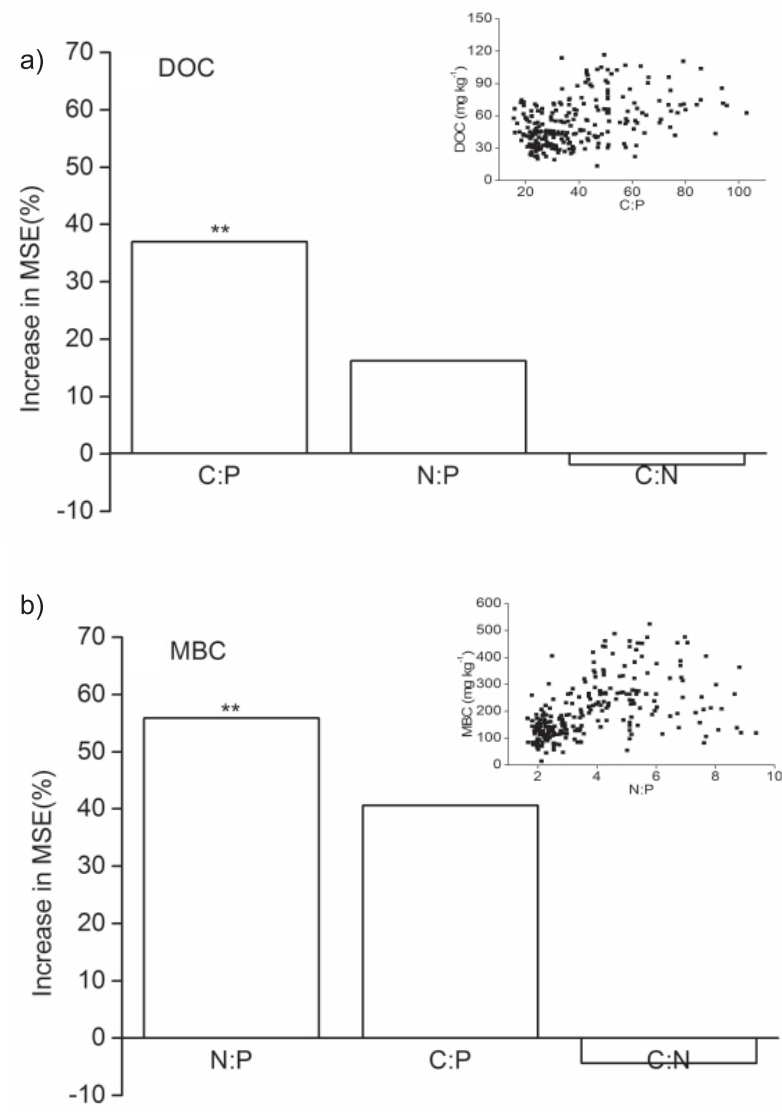

Fig. 5. Contributions of soil nutrient stoichiometries to the content of soil active organic carbon fractions at the small watershed scale (significance levels are as follows: ${ }^{*} p<0.05$ and $* * p<0.01 . \mathrm{n}=248)$.

associative storage capacities [24-25]. In the study area, the SOC content was significantly affected by land use. The mean SOC content in shrub land was 2-3 times higher than that in upland and paddy soils (Fig. 2). In shrub-land, there were relatively higher amounts of aboveground biomass and roots, resulting in relatively greater organic litter input and less soil erosion than in cropland (upland and paddy) [26]. In the cropland soils, SOC is less physically protected than in shrub land. Periodical tillage breaks up soil macro-aggregates and exposes previously protected organic matter within such aggregates [27], which increases the SOC decomposition rate and weakens organic carbon sequestration ability. Moreover, in a paddy field, the flooded-drainage circulation accelerates SOC mineralization rate because of the change of microbial community structure, biomass, and metabolic process [28-29]. The TN content in paddy was lower than in upland and shrub land (Fig. 2). Oelmann et al. [30] considered that soil management and plant species influenced $\mathrm{N}$ availability and accumulation. In shrub land, organic matter input (litter, dead roots, mycorrhizae, and exudates) leads to an increase of TN [31]. During the rice-growing season, the flooded-drainage cycle promoted the loss of nitrogen compared with upland soils. The amount of $\mathrm{P}$ in paddy soil was shown to be lower than that in upland and shrub land soils (Fig. 2). The result may be due to the reason that flooded and dry-wet conditions improved the content of Olsen-P, but accelerate the loss of P. The continuous accumulation of soil organic $\mathrm{C}$ might have occluded $\mathrm{P}$ in its organic form, thereby decreasing soil $\mathrm{P}$ availability [32].

\section{Soil Physical and Chemical Properties Influencing Soil Active Organic Carbon}

In the present study, DOC was higher in shrub-land soil than in cropland soils, which may be attributable to the limited return of straw to upland and paddy soils (Fig. 2). Furthermore, frequent disturbance of cultivated soil was considered to accelerate the mineralization and leaching loss of DOC [33-34].

Random forest revealed that an important impact factor for the content of DOC was $\mathrm{pH}$ in cropland, whereas it was SOC in shrub land. Soil pH affects selective preservation or metabolic modification of specific components (e.g., lignin-cellulose, lipids) during decomposition and therefore also has a more direct impact on soil organic matter composition. Low soil $\mathrm{pH}$ has the potential to retard organic matter decomposition [35]. Compared with shrub land, $\mathrm{pH}$ in upland and paddy was low, which was one reason to explain the obvious contribution of $\mathrm{pH}$ on DOC in croplands to some extent. In shrub land, it was easy to understand that DOC is mainly due to the decomposition of litter and humus [6].

SOM aase of $\mathrm{f} M$ cause of input $\mathrm{MBC}$, as an active fraction of SOC, has been suggested to be a sensitive indicator of changes in total SOM, and it readily responds to land use [36]. Abundant exogenous carbon from litter and root exudates in shrub land may supply a greater amount of organic carbon for microbial growth [2]. So in this study, MBC content in shrub-land soil was approximately two times larger than that in upland and paddy soils (Fig. 2). Usually, nutrients and soil physical conditions affect soil microbial biomass [24]. In the study area, the ratio of $\mathrm{C}: \mathrm{N}$ was from 10 to 11 and the growth of microorganisms is limited by carbon availability (Fig. 3). In cropland, especially in upland soil, SOC was the most important variable determining the content of MBC. In shrub land, both SOC and TN regulated the content of $\mathrm{MBC}$. In shrub land, the nutrient elements were mainly from vegetation and litter fall [37]. Soil microbial biomass pools appeared constrained primarily by soil nitrogen because of the competition for nitrogen between plants and microorganisms [8]. Therefore, TN plays an important role in regulating MBC content.

Relationship between of $\mathrm{C}, \mathrm{N}$, and $\mathrm{P}$ Stoichiometries and Soil Active Organic Carbon

It is well established that the cycling of soil $\mathrm{N}$ and $\mathrm{P}$ is tightly coupled to $\mathrm{C}$ cycling in ecosystems. 
Table 1. Correlation coefficients (Spearman's q) between soil nutrients and soil active organic carbon fractions $(* p<0.05 ; * * p<0.01)$.

\begin{tabular}{|c|c|c|c|c|c|c|c|}
\hline & SOC & DOC & MBC & TN & AN & TP & Olsen-P \\
\hline SOC & 1 & $0.506^{* *}$ & $0.391^{* *}$ & $0.892^{* *}$ & 0.117 & $0.555^{* *}$ & $-0.131^{*}$ \\
\hline DOC & & 1 & $0.411^{* *}$ & $0.492^{* *}$ & $0.183^{* *}$ & $0.301^{* *}$ & $-0.213^{* *}$ \\
\hline MBC & & & 1 & $0.337^{* *}$ & $0.177^{* *}$ & $0.150^{*}$ & $-0.401^{* *}$ \\
\hline TN & & & & 1 & 0.116 & $0.603^{* *}$ & $-0.176^{* *}$ \\
\hline AN & & & & & 1 & -0.061 & -0.085 \\
\hline TP & & & & & & 1 & 0.021 \\
\hline Olsen-P & & & & & & & 1 \\
\hline
\end{tabular}

The effects of nutrient elements on active organic carbon fractions varied among different land use depending on the specific situations encountered $[1,38]$. In the present study, the C:N ratio of soil was similar under all land use types (from 10 to 11), which illustrated that the biomass of soil microorganisms is $\mathrm{N}$ enriched As shown (Fig. 3). At the watershed scale, random forest revealed that $\mathrm{C}: \mathrm{P}$ and $\mathrm{N}: \mathrm{P}$ ratios had a significant effect on the content of DOC and $\mathrm{MBC}$, respectively. The positive relations between $\mathrm{C}: \mathrm{P}$ ratio and $\mathrm{DOC}$ indicated that the accumulation of SOC accelerated the production of DOC [39]. Combined with the result of positive relations between $\mathrm{MBC}$ and $\mathrm{AN}$ (Table 1), the positive relationship between $\mathrm{N}: \mathrm{P}$ ratio and $\mathrm{MBC}$ implies that improvement on the content of $\mathrm{TN}$, especially nitrogen availability, was helpful for the growth of soil microbial biomass $[4,8]$. From Table 1, Olsen-P was negatively correlated with $\mathrm{MBC}$, which means the growth of soil microbial biomass did not seem to be impaired by low $\mathrm{P}$ availability. $\mathrm{Hu}$ et al. [40] considered that microbial growth due to organic input is mainly dependent on the increased availability of $\mathrm{C}$ in the soil. In the study area, MBC was positively correlated with DOC (Table 1). In general, we deduced that, in karst area, high $\mathrm{C}$ and $\mathrm{N}$ availability (especially in combination with low $\mathrm{P}$ availability) is helpful to increase the soil microbial biomass. In short, SOC accumulation accelerates the increase of DOC content. Improvement of carbon and nitrogen availability was in favor of the growth of microbes.

\section{Conclusions}

In the study area it was possible that contributions of physical and chemical properties to the content of soil active organic carbon fractions was discrepant under different scales. $\mathrm{pH}$ and SOC were the most important variables determining the content of DOC in croplands (upland and paddy) and shrub land, respectively. SOC accumulation accelerates the growth of microbial biomass in upland and shrub land. In watershed scale, the accumulation of SOC promoted the increase of DOC. Although the content of Olsen-P in the shrub land appeared to be lower than that in croplands, the growth of soil microbial biomass did not seem to be impaired by $\mathrm{P}$ availability.

\section{Acknowledgements}

This research was financially supported by the National Natural Science Foundation of China (grant Nos. 41471199, 41671298, and 41601260) and the National key Research Program (2016YFD0200106-5).

\section{Conflict of Interest}

The authors declare no conflict of interest.

\section{References}

1. GAO Y., YU G.R., HE N.P. Equilibration of the terrestrial water, nitrogen, and carbon cycles: advocating a health threshold for carbon storage. Ecol. Eng. 57, 366, 2013.

2. LI Y., WU J.S., LIU S.L., SHEN J.L., HUANG D.Y., SU Y.R., WEI W.X., SYERS J.K. Is the C: N: P stoichiometry in soil and soil microbial biomass related to the landscape and land use in southern subtropical China? Global Biogeochem. Cy. 26 (4), 1, 2012.

3. LI X., WANF H., GAN S.H., JIANG D.Q., TIAN G.M., ZHANG Z.J. Eco-stoichiometric alterations in paddy soil ecosystem driven by phosphorus application. PLoS One. 8, e61141, 2013.

4. KIRKBY C.A., RICHARDSON A.E., WADE L.J., BATTEN G.D., BLANCHARD C., KIRKEGAARD J.A. Carbon-nutrient stoichiometry to increase soil carbon sequestration. Soil Biol. Biochem. 60, 77, 2013.

5. NOSRATI K., GOVERS G., SMOLDERS E. Dissolved organic carbon concentrations and fluxes correlate with land use and catchment characteristics in a semi-arid drainage basin of Iran. Catena. 95, 177, 2012.

6. VAN DEN BERG L.J.L., LAURA S., ASHMORE M.R. Dissolved organic carbon (DOC) concentrations in UK soils and the influence of soil, vegetation type and seasonality. Sci. Total Environ. 427-428, 269, 2012.

7. ZHANG J.B., SONG C.C., YANG W.Y. Land use effects on the distribution of labile organic carbon fractions 
through soil profiles. Soil Sci. Soc. Am. J. 70 (2), 660, 2006.

8. HARTMAN W.H., RICHARDSON C.J. Differential nutrient limitation of soil microbial biomass and metabolic quotients $\left(q \mathrm{CO}_{2}\right)$ : is there a biological stoichiometry of soil microbes? PLoS ONE. 8 (3), e57127, 2013.

9. SCHIMEL J.P., WEINTRAUB M.N. The implications of exoenzyme activity on microbial carbon and nitrogen limitation in soil: a theoretical model. Soil Biol. Biochem. 35 (4), 549, 2003.

10. SINSABAUGH R.L., HILL B.H., FOLLSTAD SHAH J.J. Ecoenzymatic stoichiometry of microbial organic nutrient acquisition in soil and sediment. Nature. 462, 795, 2009.

11. ARNALDS A. Carbon sequestration and the restoration of land health. Climatic Change. 65 (3), 333, 2004.

12. PENG T., WANG S.J. Effects of land use, land cover and rainfall regimes on the surface runoff and soil loss on karst slopes in southwest China. Catena. 90, 53, 2012.

13. YANG X.Q., HU B.Q. Quality characteristics of soils in karst rocky-desertified areas with ecosystem under restoration succession - a case study of Chengjiang subwatershed, Duan county, Guangxi. Journal of Ecology and Rural Environment. 25 (3), 1, 2009 [In Chinese].

14. ZHANG W., CHEN H.S., WANG K.L., SU Y.R., ZHANG J.G., YI A.J. The heterogeneity and its influencing factors of soil nutrients in preak- cluster depression areas of karst region. Agr. Sci. China. 6 (3), 322, 2007.

15. LU X.Q., TODA H., DING F.J., FANF S.Z., YANG W.X., XU H.G. Effect of vegetation types on chemical and biological properties of soils of karst ecosystems. Eur. J. Soil Biol. 61, 49, 2014.

16. PEÑUELAS J., POULTER B., SARDANS J., CIAIS P., VAN DER VELDE M., BOPP L., BOUCHER O., GODDERIS Y., HINSINGER P, LLUSIÀ J., NARDIN E., VICCA S., Obersteiner M., JANSSENS I.A. Humaninduced nitrogen-phosphorus imbalances alter natural and managed ecosystems across the globe. Nat. Commun. 4, 2064, 2013.

17. NELSON D.W., SOMMERS L.E. Total carbon, organic carbon and organic matter, in: A.L. Page, R.H. Miller, D.R. Keeney (Eds.), Methods of soil analysis, part 2, chemical and microbiologiacl properties, 2nd edn. American Society of Agronomy, Inc., Madison, 539, 1982.

18. BREMNER J.M., Nitrogen-total, in: D.L. Sparks (Eds.), Methods of soil analysis: chemical methods, part 3, Soil Science Society of America, Inc., Madison, 1085, 1996.

19. BAO S.D. Soil and Agricultural Chemistry Analysis. China Agriculture Press, Beijing, China, 46, 2000 [In Chinese].

20. CAMBARDELLA C.A., MOORMAN T.B., PARKIN T.B., KARLEN D.L., NOVAK J.M., TURCO R.F., KONOPKA A.E. Field-scale variability of soil properties in central iowa soils. Soil Sci. Soc. Am. J. 58 (5), 1501, 1994.

21. PIERZYNSKI G.M. Methods of Phosphorus Analysis for Soils, Sediments, Residuals, and Waters. North Carolina State University, Raleigh, 2000.

22. WU J.S., JOERGENSEN R.G., POMMERENING B., CHAUSSOD R., BROOKES P.C. Measurement of soil microbial biomass $\mathrm{C}$ by fumigation- extraction- an automated procedure. Soil Biol. Biochem. 22 (8), 1167, 1990.

23. DELGADO-BAQUERIZO M., GALLARDO A., COVELO F., PRADO-COMESAÑNA A., OVHOA V., MAESTRE F.T. Differences in thallus chemistry are related to species-specific effects of biocrust-forming lichens on soil nutrients and microbial communities. Funct. Ecol. 29 (8), 1087, 2015.

24. ZHU H.H., WU J.S., GUO S.L., HUANG D.Y., ZHU Q.H., GE T.D. LEI T.W. Land use and topographic position control soil organic $\mathrm{C}$ and $\mathrm{N}$ accumulation in eroded hilly watershed of the Loess Plateau. Catena. 120, 64, 2014.

25. FERNÁNDEZ-ROMERO M.L., LOZANO-GARCÍA B., PARRAS-ALCANTARA L. Topography and land use change effects on the soil organic carbon stock of forest soils in Mediterranean natural areas. Agr. Ecosyst. Environ. 195, 1, 2014.

26. WANG J., FU B., QIU Y., CHEN L. Soil nutrients in relation to land use and landscape position in the semiarid small catchment on the loess plateau in China. J. Arid Environ. 48 (4), 537, 2001.

27. LIU S.L., DONG Y.H., CHENG F.Y., YIN Y.J., ZHANG Y.Q. Variation of soil organic carbon and land use in a dry valley in Sichuan province, Southwestern China. Ecol. Eng. 95, 501, 2016.

28. CHAPLOT V., ABDALLA K., ALEXIS M. BOURENNANE H., DARBOUX F., DLAMINI P., EVERSON C., MCHUNU C., MULLER-NEDEBOCK D., MUTEMA M., QUENEA K., THENGA H., CHIVENGE P. Surface organic carbon enrichment to explain greater $\mathrm{CO}_{2}$ emissions from short-term no-tilled soils. Agr. Ecosyst. Environ. 203 (1), 110, 2015.

29. ZHANG G.S., NI Z.W. Winter tillage impacts on soil organic carbon, aggregation and $\mathrm{CO}_{2}$ emission in a rainfed vegetable cropping system of the mid-Yunnan plateau, China. Soil Till. Res. 165, 294, 2017.

30. OELMANN Y., BUCHMANN N., GLEIXNER G., HABEKOST M., ROSCHER C., ROSENKRANZ S., SCHULZE E.D., STEINBEISS S., TEMPERTON V.M., WEIGELT A., WEISSER W.W., WILCKE W. Plant diversity effects on aboveground and belowground $\mathrm{N}$ pools in temperate grassland ecosystems: development in the first five years after establishment. Global Biogeochem. Cy. 25, GB2014, 2011.

31. PRIETZEL J., BACHMANN S. Changes in soil organic $\mathrm{C}$ and $\mathrm{N}$ stocks after forest transformation from Norway spruce and Scots pine into Douglas fir, Douglas fir/spruce, or European beech stands at different sites in Southern Germany. Forest Ecol. Manag. 269, 134, 2012.

32. HUANG W.J., ZHOU G.Y., LIU J.X. Nitrogen and phosphorus status and their influence on aboveground production under increasing nitrogen deposition in three successional forests. Acta Oecol. 44 (SI), 20, 2012.

33. SOWERBY A., EMMETT B.A., WILLIAMS D., BEIER C., EVANS C.D. The response of dissolved organic carbon (DOC) and the ecosystem carbon balance to experimental drought in a temperate shrubland. Eur. J. Soil Sci. 61 (5), 697, 2010.

34. SEEDRE M., SHRESTHA B.M., CHEN H.Y.H., COLUMBO S., JÕGISTE K. Carbon dynamics of North American boreal forest after stand replacing wildfire and clearcut logging. J. Forest Res. 16 (3), 168, 2011.

35. KEMMITT S.J., WRIGHT D., KWT G., JONES D.L. $\mathrm{pH}$ regulation of carbon and nitrogen dynamics in two agricultural soils. Soil Biol. Biochem. 38 (5), 898, 2006.

36. WAREMBOURG F.R., ROUMET C., LAFONT F. Differences in rhizosphere carbon partitioning among plant species of different families. Plant Soil. 256 (2), 347, 2003.

37. SARDANS J., RIVAS-UBACH A., PEÑUELAS J. The $\mathrm{C}: \mathrm{N}: \mathrm{P}$ stoichiometry of organisms and ecosystems in 
a changing world: a review and perspectives. Perspect. Plant Ecolo. 14, 33, 2012.

38. GAO Y., ZHU B., ZHOU P., TANG J.L., WANG T., MIAO C.Y. Effects of vegetation cover on phosphorus loss from a hillslope cropland of purple soil under simulated rainfall: a case study in China. Nutr. Cycl. Agroecosys. 85 (3), 263, 2009.

39. KALBITZ K., SOLINGER S., PARK J.H., MICHALZIK B., MATZNER E. Controls on the dynamics of dissolved organic matter in soils: a review. Soil Sci. 165 (4), 277, 2000.

40. HU N., LI H., TANG Z., LI Z.F., LI G.C., JIANG Y., HU X.M., LOU Y.L. Community size, activity and $\mathrm{C}: \mathrm{N}$ stoichiometry of soil microorganisms following reforestation in a Karst region. Eur. J. Soil Biol. 73, 77, 2016. 
